\title{
IOWA THROUGH EYES OF A TEN-YEAR-OLD
}

\section{By HERBERT HOOVER*}

There is no man or woman born in Iowa who is not proud of his native state. The good Lord originally made it the richest stretch of agricultural land that ever blessed any one single commonwealth. It was populated by the more adventurous and the more courageous, who fought their way along the ever-extending frontier. They builded there in a short period, less than a century, a people who today enjoy the highest standard of living, the highest average intelligence, the highest average degree of education that has ever rewarded the free enterprise of men.

I could talk to you today about the greatness of Iowa. I could give you vast statistics of its growth and power. I could mention the great Americans it has produced and the contributions it has made to national life.

But I prefer to think of Iowa as I saw it through the eyes of a ten-year-old boy. And the eyes of any tenyear-old Iowa boy are filled with the wonders of Iowa's streams and woods, of the mystery of growing crops. All boys and girls must discover the world all over again, and Iowa's sons and daughters are self-starting devices with enormous potential energy. Their days are filled with adventure and great undertakings, with participation in good and comforting things.

I was taken farther west from Iowa when I was ten, to Oregon and thence to that final haven of IowansCalifornia-where I have clung ever since. Someone may say that my recollections of Iowa are only the illusions of sixty years after, but I know better-for I have been back and checked it up. I was told that when I went back everything would have shrunk up and become small

\footnotetext{
- Excerpts from an address by former president Herbert Hoover before the Iowa Association of Southern California, at Bixby Park, Long Beach, California, on occasion of honoring his birthday anniversary, August 11, 1945.
} 
and ordinary. For instance, there was Cook's Hill-that great, long hill where, on winter nights, we slid down at terrific speeds with our tummies tight to home-made sleds. I've seen it several times since; it's a good hill. But the method of thawing out frozen toes with icewater is now obsolete.

The swimming-hole under the willows down by the railroad bridge is still operating efficiently, albeit modern mothers probably compel their youngsters to take a bath to get rid of the mud when they come home.

At this very time there are rabbits still being trapped by small boys in cracker-box traps held open by a figure four. One of the bitterest days of my life was in connection with a rabbit. Rabbits fresh from a figure-four trap early on a cold morning are wiggly rabbits, and in the lore of boys of my time it was better to bring them home alive. My brother, being older, had surreptitiously behind the blacksmith shop read in the Youth's Companion full directions for rendering live rabbits secure. I say "surreptitiously," for mine was a Quaker family unwilling in those days to have youth corrupted with stronger reading than the Bible, the encyclopedia or those great novels where the hero overcomes the demon rum. Soon after my brother had acquired this higher learning on rabbits, he proceeded to instruct me to stand still in the cold snow and hold up the rabbit by its hind feet while with his not over-sharp knife he proposed to puncture two holes between the sinews and back knee joints of the rabbit, through which holes he proposed to tie a string and thus arrive at complete security. Upon this surgical operation the resistance of this rabbit was too much for me. I was not only blamed for its escape all the way home and for weeks afterwards, but continuously over the last fifty years. I had thought sometimes that I would write the Youth's Companion and suggest they make sure that this method is altered.

There were also at times prairie chickens in the hedges. By firing volleys of slingshots and arrows we were sometimes able to bring down a chicken. There may have 
been unavoidable mistakes by confusing barnyard chickens with the wild ones. The Waldorf Hotel has never yet provided game of such wondrous flavor as this halfcooked bird over a camp fire.

And in those days there were sunfish and catfish to be had. Nor did we possess the modern equipment of incantation of fish with all its artificial lures, tackle assembled from the steel of Damascus, the bamboos of Siam, tin of Bangkok, the lacquor of China or silver of Colorado. We were still in that rude but highly social condition of using a willow, pole with a butcher string line and hooks ten for a dime. We lived in the time when fish used to bite instead of strike and we knew it bit when the cork bobbed. Our compelling lure was a segment of an angleworm and our incantation was to spit on the bait.

And in the matter of eating, my recollections of Iowa food are of the most distinguished order. You may say that is the appetite of youth, but $I$ have also checked this up. At later stages in my life, I had opportunity to eat both the very best food in the world, and also the very worst. When I ate of the best I was still sure that Aunt Millie was a better cook. Some thirty years after this time, in visiting Aunt Millie, I challenged that dear old lady, then far along in years, to cook another dinner of the kind she provided on Sabbath days when we were both youthful. She produced that dinner, and again proved Iowa to be the best-fed part of this hungry world.

And there was the Burlington railway track. It was a place of wonders. The track was ballasted with glacial gravels where on the industrious search you discovered gems of agate and fossil coral. They could with infinite backache be polished on the grindstone. Their fine points came out wonderfully when wet, and you had to lick them with your tongue before each exhibit.

But Iowa through the eyes of a ten-year-old boy is not all adventure or high living. Iowa in those years, as in these years, was filled with days of school. And who 
does not remember with a glow that sweet-faced lady who with infinite patience and kindness drilled into us those foundations of all we know today? And they were days of chores and labor. I am an agitator against factory labor for children, but I have never joined with those who clamored against proper chores for children outside their school hours. And I speak from the common experience of most Iowa children of my day in planting corn, hoeing gardens, learning to milk, sawing wood, and the other proper and normal occupations for boys.

The prevailing rate for picking potato bugs was one cent a hundred, and if you wanted firecrackers on the Fourth of July you took it or left it. We were not allowed to have a Union of Potato Bug Pickers. However, if that wage still prevails, it would be entitled to a hearing by the Labor Board. It may be that the use of arsenic on bugs has created technological unemployment of bug hunters. If so, the recent remedy would be to dig up the potatoes while they are young.

In Iowa came my earliest realization of the stir of national life through the torch parade in the Garfield campaign of 1880 . On that night I was not only allowed out-but I saw the lamps being filled and lighted. There was no great need for urging voters in our villagethere was one Democrat in the town. He occasionally fell to the influence of liquor, therefore in the esteem of our group he represented all the forces of evil. At times he relapsed to goodness, in the form of rations of a single gumdrop to the small boys who did errands at his store. He also bought the old iron from which extra financial resources were provided for firecrackers on the Fourth of July. He was, therefore, tolerated and he served efficiently as a moral and political lesson.

Another touch of national life was the assassination of Garfield. The flag at the crossroads was placed at half-mast. All the people moved in hushed and anxious hours while his life lingered on. It was thus I first 
learned that a great government presided over the welfare of our people.

The occasion today is dedicated to renewal of old acquaintances and recall of happy days. Yet despite our will we cannot curtain from our minds the gigantic events which surround us. The specters of war and revolution stand behind every shoulder. They haunt every thought and our every word. Every one of us has some relative dear to us in this war. Every one of us is making sacrifices that victory may come to our arms.

Today fifteen million boys have joined the armed services. They have gone into battle gladly and with courage because they believed they were preserving America for free men. A million have been wounded or have died that America may be free. Those who survive look to a return to the free America they have known.

I say to you that for three centuries, from Plymouth Rock to this very day, the American Way has moved men to deeds of daring, of unimaginable bravery. They crossed a perilous ocean for it; they traversed the desert and fought men and beasts for it; they labored and dreamed and invented and sweated and bled for it. They have fought four great wars for it.

Is it not a faith? Is it not a belief for which men die? Is freedom to be defeated by slogans, or foreign propaganda, or Fifth Columns? You and I must not be marked as the generation who surrendered the heritage of America. 
Copyright of Annals of Iowa is the property of State of Iowa, by \& through the State Historical Society of Iowa and its content may not be copied or emailed to multiple sites or posted to a listserv without the copyright holder's express written permission. However, users may print, download, or email articles for individual use. 